LIAMES 12 - pp. 189-193, Primavera 2012

Eduardo Rivail Ribeiro (Max Planck Institute for Psycholinguistics/DoBeS \& UFPA)

\title{
Final consonants in Maxakalí and their comparative status
}

\begin{abstract}
Although final-consonant correspondences between Proto-Jê and Maxakalí tend to be straightforward, in some cases the comparative data seem to suggest that Maxakalí has actually undergone a major innovation, through the accretion of final consonants to originally vowel-final roots. This hypothesis is further corroborated by the study of loanwords from both Portuguese and Old Tupí.
\end{abstract}

Davis (1968) constitutes the first attempt at applying the comparative method to investigate the relationship between Maxakalí and the Jê family. ${ }^{1}$ Although his study was based on a faulty reconstruction of Proto-Jê and limited Maxakalí data, Davis made lasting contributions to the comparative knowledge of Macro-Jê; much of the phonological correspondences he detected are being further corroborated — and refined — by additional comparative studies (Ribeiro 2005, 2007). ${ }^{2}$ Among other findings, ongoing comparative studies reveal that, when compared to Proto-Jê, final consonants in Maxakalí fit into three different categories:

(1) Consonants which correspond clearly with final consonants in Proto-Jê and actual Jê languages:

$\begin{array}{lllll}\text { (1a) Proto-Jê *prãm } & \text { 'hunger’ } & :: & \text { Maxakalí } & \text { putup } \\ \text { (1b) Proto-Jê *j-õt } & \text { 'to sleep' } & :: & \text { Maxakalí } & \text {-yõn }\end{array}$

\footnotetext{
${ }^{1}$ Of course, obvious similarities between Maxakalí and Jê languages had been pointed out early on; for a historical overview of comparative Macro-Jê linguistics, see Rodrigues (2002). Maxakalí data are from Popovich \& Popovich (2005); Proto-Jê reconstructions are from Ribeiro (2005); Old Tupí data are from Barbosa (1970). Maxakalí data are given in the language's practical ortography (for pronunciation details, see Popovich \& Popovich 2005). Thanks are due to Sandro Campos (UFMG), for kindly sharing his data and valuable insights on Maxakalí.

${ }^{2}$ Such comparative studies are based on a recent surge in descriptive materials on several Jê and Macro-Jê languages-including Maxakalí, for which there is now a dictionary (Popovich \& Popovich 2005), in addition to phonological (Araújo 2000, Wetzels 2009) and grammatical (Pereira 1992, Campos 2009) studies.
} 
(2) Consonants corresponding with final consonants which, although absent in most Jê languages, were actually present in Proto-Jê (as suggested by morphophonemic alternations found in daughter languages). For instance, while most Jê languages have codaless reflexes of Proto-Jê *njo( $p$ ) 'to hang' (cf. Apinajé (Northern Jê) ndzo; Oliveira 2005: 41), Kaingáng has three different reflexes: sa, sàv, and sam (Wiesemann 2002); sàv can arguably be seen as the underlying form, whereas sam is likely the result of the suffixation of the causativizer $-n$ to sàv (cf. Cavalcante 1987: 46). Combined with such internal evidence, the occurrence of a final consonant in the Maxakalí cognate helps corroborate the reconstruction of a final $* p$ for the Proto-Jê form:

(2a) Proto-Jê * njo(p) 'to hang' : : Maxakalí xup

A similar example is the word for 'ashes', which occurs with a final consonant in Southern Jê (Kaingáng $m r e ̃ j)$, but not in Northern (Apinajé $m r$ ) and Central Jê (Xavante pro) languages. Considering that final Proto-Jê *k occurs in Kaingáng as /j/ (cf. Proto-Jê *prek 'fart'> Kaingáng prej), a likely reconstruction for this root in Proto-Jê is *mro(k). Maxakalí, once again, corroborates such a reconstruction (2b):

(2b) Proto-Jê *mro (k) 'ashes' :: Maxakalí putok

(3) Consonants which seem to have been added to an otherwise vowel-final root. That would have been the case of kutex 'to sing' and yõg 'possession marker':

\begin{tabular}{|c|c|c|c|}
\hline (3a) Proto-Jê * $\eta r \varepsilon$ & 'to sing, dance' & :: & Maxakalí \\
\hline (3b) Proto-Jê $* j-\tilde{o}$ & 'possession marker' & & Maxakalí \\
\hline
\end{tabular}

While examples fitting categories (1) and (2) are, from a comparative viewpoint, rather straightforward, examples of the last category (3) are somewhat challenging. After all, accretion of phonological material is harder to argue for than its opposite. If consonant accretion is to be seen as a regular diachronic process, one needs to detect the underlying rules determining which (and, hopefully, how, and why) consonants were inserted, demonstrating that consonants were not added at random, but rather following regular phonological rules.

A major problem is the fact that, given the current level of knowledge of Macro-Jê, one cannot in principle be absolutely sure whether examples of the 3 rd type actually involve accretion in Maxakalí, rather than being another instance in which Maxakalí turns out to be more conservative than (most) Jê languages, such as in (2). Fortunately enough, however, there are 
loanwords which seem to clearly prove that, historically, consonants were indeed added to vowel-final words in Maxakalí.

Loanwords commonly discussed in the literature (Wetzels 2009) involve Portuguese paroxitona words (i.e., those whose stress falls on the penultimate syllable), whose final vowels (if any) are eliminated in the Maxakalí corresponding forms: e.g. hetanat 'picture' (< Portuguese retrato). The examples which will concern us here, on the other hand, involve vowel-final words whose stress falls on the last syllable, either because that was the situation in the donor language (e.g. 'blanket'), or because the stress was switched to the last syllable (e.g. 'money', 'horse'). That includes a few Old Tupí loans (apud Ribeiro 2009), in addition to Portuguese ones:

\begin{tabular}{|c|c|c|}
\hline (4) ãmãnex & 'priest' & (< Tupí abaré) \\
\hline (5) kapex & 'coffee' & (<Portuguese café) \\
\hline (6) ämix & 'needle' & (< Tupí abi) \\
\hline (7) tayũmak & 'money' & (< Tupí itajúb-a) \\
\hline (8) kamanok & 'horse' & (< Portuguese cavalo, possibly via Tupí cabarú) \\
\hline (9) komenok & 'blanket' & ( $<$ Portuguese cobertor, probably via colloquial cobertô) \\
\hline (10) kapitõg & 'chief ${ }^{4}$ & (< Portuguese capitão) \\
\hline (11) pẽyõg & 'beans' & (<Portuguese feijão) \\
\hline
\end{tabular}

${ }^{3}$ Although the study of loanwords has played an important role in the analysis of Maxakalí phonology, I am unfamiliar with any previous work dealing with the insertion of final consonants. Wetzels (2009) mentions, in passing, that "a word-final syllable that is stressed in BP [Brazilian Portuguese] may be closed with a consonant in Maxacalí, as in café 'coffee' [ka'fe] > Max [ka'pec]." Another loanword mentioned by Wetzels seems at first to be an additional example of final consonant insertion (Portuguese moto ['moto] 'motorcycle', Maxakalí [mõ'tok]), but that would be an exceptional case, since final consonants tend to be added to words ending in stressed syllables. Most likely, the loan is derived from colloquial BP motoca [mo'toka], instead of moto. (A paroxítona Portuguese word such as moto, on the other hand, would lose its final vowel in Maxakalí, showing up as $/ \mathrm{mott} /$ or $/ \mathrm{mot} /$, presumably.)

${ }^{4}$ In examples such as kapitõg and pẽyogg, the Portuguese diphthong [ãw] is apparently reflected as [õ] in Maxakalí, with the final accretion of a nasal velar consonant. In recent loanwords, according to Sandro Campos (p.c., August 13, 2012), the Portuguese diphthong is reflected as a diphthong in Maxakalí (cf. xãmãm [t]ãmãwm] 'soap' < Portuguese sabão). Since nasal diphthongs such as these are (phonetically) common in the native Maxakalí lexicon (cf. mãhãm 'fish', 'ónyãm 'porcupine', etc.), the possibility that kapitõg and peyõg are indirect loans cannot be discarded. Another Tupí loan, mentioned by Campos (2011), may also have involved consonant accretion: tapayõg 'Black person' $(<$ Tupí tapyyiún- $a)$. 
In addition to those Tupí loans listed by Ribeiro (2009), which are part of the common lexicon, a few are restricted to a special linguistic repertoire used with ritual songs (yãmĩy-xop); Campos (2009: 30) mentions two examples, both of which also display consonant accretion:

$\begin{array}{lll}\text { kõnõmĨy } & \text { 'boy' } & (<\text { Tupí curumĩ) } \\ \text { kõyãg } & \text { 'woman' } & \text { (< Tupí cunhã) }\end{array}$

Even within such a limited sample, a few tendencies can be observed: words ending in front vowels tend to add a final palatal consonant, words ending in back oral vowels tend to add a final velar stop, etc. More importantly still, loanword behavior tends to mirror our hypothetical accretion of final consonants to inherited vowel-final roots (cf. kapex 'coffee', kutex 'to sing'; kapitõg 'chief', yõg 'possession').

Thus, the loanwords listed above (4-13) seem to strongly corroborate the hypothesis that consonants were indeed added to vowel-final stems in Maxakalí (probably to fulfill syllabic constraints), their properties being determined by the quality of the preceding vowel. ${ }^{5}$ Besides the comparative value of such information, it may contribute to reveal yet another facet of the oft-mentioned "intimacy" between consonantal and vowel features (Gudschinsky, Popovich, \& Popovich 1970) in this fascinating language.

\section{REFERENCES}

ARAÚJO, Gabriel Antunes de (2000). Fonologia e morfologia da língua Maxakalí. Master's thesis. Campinas, SP.: IEL/UNICAMP.

BARbOSA, A. Lemos (1970). Pequeno Vocabulário Português-Tupi. Rio de Janeiro: Livraria São José.

CAMPOS, Carlo Sandro de Oliveira (2009). Morfofonêmica e morfossintaxe da língua Maxakalí. Doctoral dissertation. Belo Horizonte, MG.: UFMG.

.(2011). Considerações sobre a língua usada nos cantos Maxakalí. In Ana Suelly Arruda Câmara Cabral et al. Línguas e culturas Macro-Jê. Vol. 2, pp. 171-193. Brasília: Laboratório de Línguas Indígenas/UnB; Campinas, SP: Curt Nimuendajú.

CAVAlCANTE, Marita Pôrto (1987). Fonologia e morfologia da língua Kaingang: o dialeto de São Paulo comparado com o do Paraná. Doctoral dissertation. Campinas, SP.: IEL/UNICAMP.

DAVIS, Irvine (1968). Some Macro-Je Relationships.International Journal of American Linguistics 34(1): $42-47$.

GUDSCHINSKY, Sarah C.; POPOVICH, Harold; POPOVICH, Frances B. (1970). Native reaction and phonetic similarity in Maxakalí phonology. Language 46(1): 77-88.

${ }^{5}$ Synchronically, there seems to remain a constraint against final open syllables. However, as illustrated by recent loanwords (Sandro Campos, p. c., June 6, 2012), consonant accretion is no longer sensitive to the quality of the preceding vowel, a glottal stop being added no matter what the preceding vowel is: pino' 'turkey' (< Portuguese peru), xenona' 'celular phone' (< Portuguese celular, via colloquial Portuguese celulá), nemene' 'DVD' (< Portuguese devedê), etc. 
Ribeiro: Final consonants in Maxakalí And their comparative status.

OLIVEIRA, Christiane Cunha de (2005). The language of the Apinajé people of Central Brazil. Ph. D. dissertation. Eugene: University of Oregon.

PEREIRA, Deuscreide Gonçalves (1992). Alguns aspectos gramaticais da língua Maxakalí. Master's thesis. Belo Horizonte, MG.: UFMG.

POPOVICH, A. Harold; POPOVICH, Frances B. 2005. Dicionário Maxakali-Português. Cuiabá: Sociedade Internacional de Linguística.

RIBEIRO, Eduardo Rivail (2005). A reconstruction of Proto-Jê (and its consequences for the Macro-Jê hypothesis). Paper presented at the International Symposium on Historical Linguistics. Belém: MPEG \& UFPA.

.(2007). Eastern Macro-Jê: A hypothesis on the internal classification of the Macro-Jê stock. Ms. .(2009). Tapuya connections: language contact in eastern Brazil. LIAMES 9: 61-76.

RODRIGUES, Aryon Dall'Igna (2002). Para o estudo histórico-comparativo das línguas Jê. In Ludoviko dos Santos; Ismael Pontes (orgs.). Línguas Jê: estudos vários, pp. 1-14. Londrina: Editora UEL.

WETZELS, W. Leo (2009). Nasal harmony and the representation of nasality in Maxacalí: evidence from Portuguese loans. In Andrea Calabrese; W. Leo Wetzels (eds.). Loan phonology, pp. 241-270. Amsterdam: John Benjamins.

WIESEMANN, Ursula (2002). Dicionário bilíngue Kaingang-Português. Curitiba: Editora Evangélica Esperança.

Recebido: $10 / 4 / 2012$

Versão revista (1): 2/9/2012

Versão revista (2): 18/9/2012

Aceito: 25/9/2012. 